
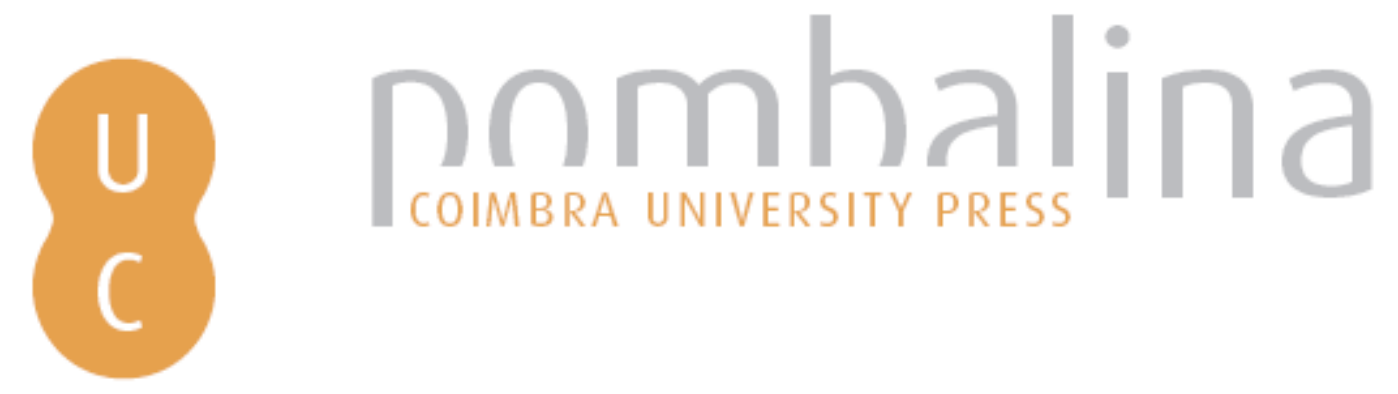

\title{
Different measures of future orientation may yield opposite predictions of environmental attitudes and behavior
}
Autor(es):
Carmi, Nurit
Publicado por: Imprensa da Universidade de Coimbra
URL
persistente:
URI:http://hdl.handle.net/10316.2/38632
DOI:
DOI:http://dx.doi.org/10.14195/978-989-26-0775-7_28
Accessed : $\quad$ 26-Apr-2023 10:25:41

A navegação consulta e descarregamento dos títulos inseridos nas Bibliotecas Digitais UC Digitalis, UC Pombalina e UC Impactum, pressupõem a aceitação plena e sem reservas dos Termos e Condições de Uso destas Bibliotecas Digitais, disponíveis em https://digitalis.uc.pt/pt-pt/termos.

Conforme exposto nos referidos Termos e Condições de Uso, o descarregamento de títulos de acesso restrito requer uma licença válida de autorização devendo o utilizador aceder ao(s) documento(s) a partir de um endereço de IP da instituição detentora da supramencionada licença.

Ao utilizador é apenas permitido o descarregamento para uso pessoal, pelo que o emprego do(s) título(s) descarregado(s) para outro fim, designadamente comercial, carece de autorização do respetivo autor ou editor da obra.

Na medida em que todas as obras da UC Digitalis se encontram protegidas pelo Código do Direito de Autor e Direitos Conexos e demais legislação aplicável, toda a cópia, parcial ou total, deste documento, nos casos em que é legalmente admitida, deverá conter ou fazer-se acompanhar por este aviso.

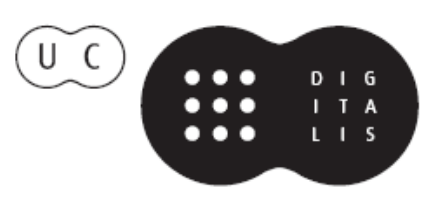




\section{INTERNATIONAL \\ STUDIES IN TIME \\ PERSPECTIVE}

MARIA PAULA PAIXÃO

JOSÉ TOMÁS DA SILVA

(COORD.)

VICTOR ORTUÑO

PEDRO CORDEIRO

(EDITORS)

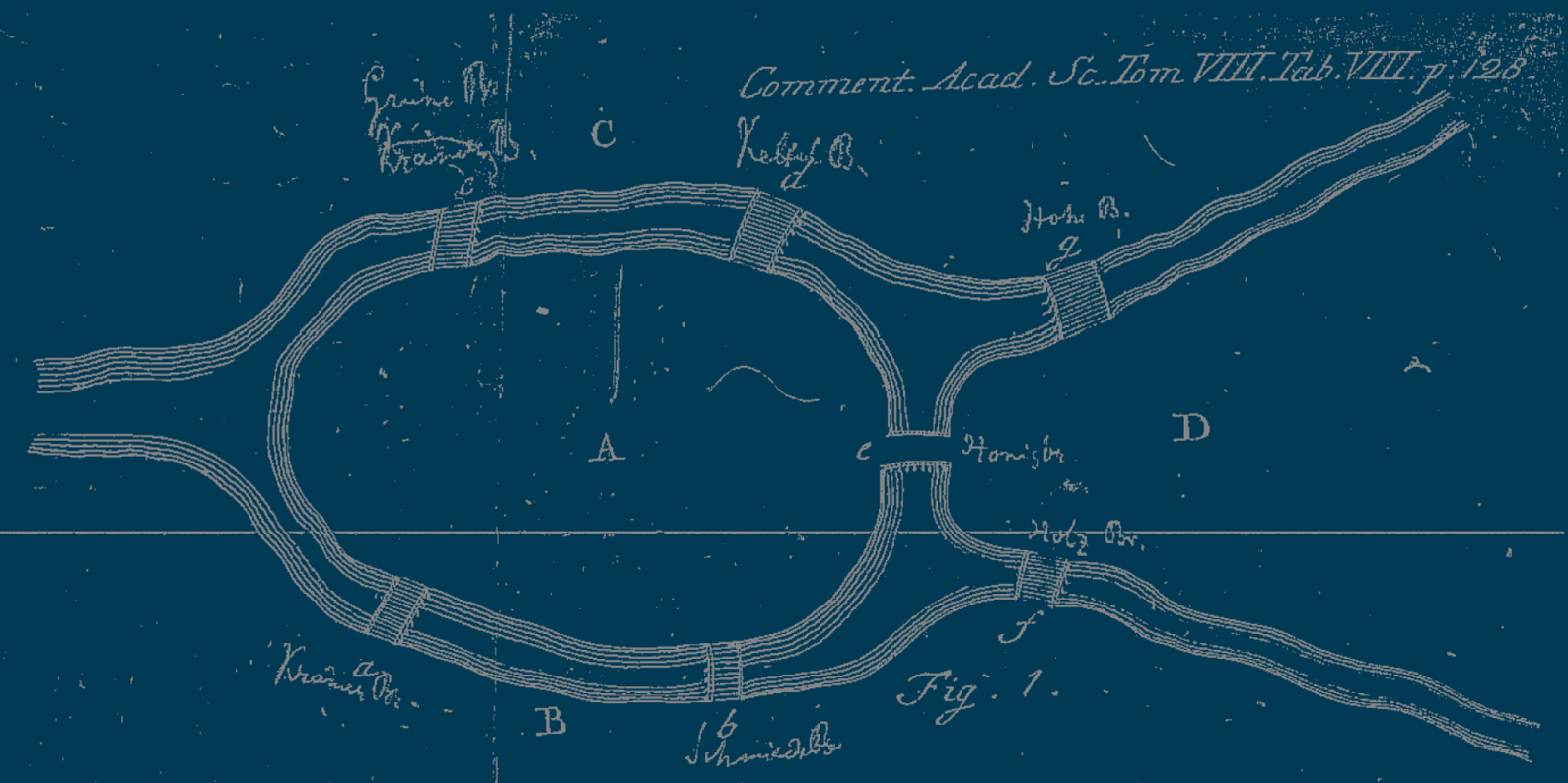

IMPRENSA DA

UNIVERSIDADE

DE COIMBRA

COIMBRA

UNIVERSITY

PRESS 


\title{
Chapter 28 \\ DIFFERENT MEASURES OF FUTURE ORIENTATION MAY YIELD OPPOSITE PREDICTIONS OF ENVIRONMENTAL ATTITUDES AND BEHAVIOR
}

\author{
Nurit Carmi \\ Environmental Sciences Department, Tel-Hai College, Israel \\ nuritcar@telhai.ac.il
}

\begin{abstract}
Aвstract: Future orientation (FO) expresses interpersonal differences affecting the creation of attitudes and behavior in many life areas. FO is a prerequisite of sustainability, which requires considering environmental consequences for future generations. This study compared between two primary measures of FO: Zimbardo's Future Time Perspective (F-ZTP) and Consideration of Future Consequences scale (CFC), in the environmental context. While higher values of CFC predicted significantly higher levels of environmental variables, higher values of F-ZTP did not predict higher levels, and in some cases even predicted significantly lower levels of environmental variables. These findings suggest that different constructs capture different dimensions of FO; while F-ZTP seems to capture personal-only aspects of FO, CFC relates to more general aspects of FO, including, but not only, personal realms. When temporal conflicts involve social conflicts, as in most environmental conflicts, an inconsistency between the predictabilities of the constructs may emerge, revealing a conflict between the "futures" people are orienting at.
\end{abstract}

Keywords: future orientation, zimbardo time-perspective, consideration of future consequences, environmental attitudes, environmental behavior.

\section{INTRODUCTION}

Future orientation (FO) is an inseparable component of the skills required by an individual or by society to protect nature, to recognize and take responsibility for the state of the environment for future generations and to be committed to a sustainable way of life. Considering its importance for environmental education and communication, great interest has been aroused in the study of FO in its environmental context (for a review, see Joireman, 2005). The two primary tools that have been used in contemporary research are: 1. Future Orientation construct included in Zimbardoss Time Perspective Inventory (F-ZTPI) (Zimbardo \& Boyd, 1999) and 2. The Consideration of Future Consequences (CFC) Scale (Strathman et al., 1994). The F-ZTPI assesses the tendency to plan for and achieve future goals, to be organized and efficient in the use of time in order to fulfill many tasks and reach high standards (For a broad international review of research on ZTPI, see Zimbardo \& Boyd, 2008; or www.timeperspective.com). CFC assesses «the extent to which individuals consider the potential distant outcomes of their current behaviours and the extent to which they are influenced by these potential outcomes" (For a review, see Joireman, 2005). Most studies have used either CFC or F-ZTPI as a measure for FO. The 
few that have used both constructs simultaneously concluded that both constructs share common characteristics, yet there are differences which should be considered (Adams and Nettle, 2009; Crocket, Weinman, Hankins, and Marteau, 2009). To date, no study has yet investigated FO simultaneously with CFC and F-ZTP on the same issue in the environmental realm. The present study aims at comparing the patterns with which the two instruments predict various environmental variables. Such a comparison is important for two reasons: The first reason relates to a general methodological aspect of measuring FO. In light of the inconsistency between the two FO measures, hinted by the abovementioned studies, the question is: What aspects of FO do they actually capture? Analysis of inconsistency between the two constructs, if revealed, may contribute to every study that uses either of these constructs as measures of FO, and may help to choose the appropriate construct. The second reason relates to the specific studied context: the environmental realm. If the development of FO is a key factor in promoting environmental attitudes and behavior, it is especially important to be well acquainted with the tool(s) for measuring FO.

\section{METHOD}

The study is based on an internet convenience sample (Qualtrics Research, Suite 2011) distributed by email and by Facebook $(n=361 ; 69.5 \%$ females, mean age \pm SD $32.2 \pm 12.1$ years). Each respondent completed CFC, F-ZTP and environmental questionnaires. Environmental attitudes, perceived severity of environmental problems, environmental efficacy, and willingness to sacrifice for the sake of the environment were assessed with a questionnaire already developed and validated by Peer, Goldman \& Yavetz (2007), to be used on an Israeli student population. They made a distinction between environmental behaviors with personal benefit and behaviors that lack personal benefit (Goldman, Yavetz $\&$ Peer, 2006). We used two of their items to measure engagement in environmental behaviors that have personal benefit (saving water and electricity) (Cronbach's $\alpha=.57$ ) and four items to assess behaviors not involving personal benefit (for example, picking up trash that others have thrown away when going out into nature or gathering newspapers and used papers and bringing them to bins for recycling (Cronbach's $\alpha=.66$ ).

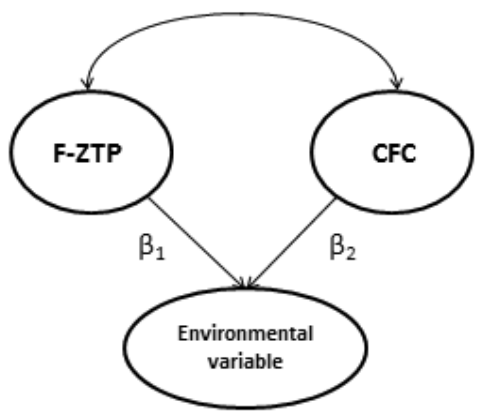

Figure 1. General SEM model of the effects of FO, measured by CFC vs. F-ZTP, on environmental variable $\left(\beta_{1}\right.$ and $\beta_{2}$ are regression coefficients of F-ZTP and CFC, respectively.) 


\section{Statistical analyses}

The regression coefficients of F-ZTPI and CFC on each of the environmental variables were calculated separately using a structural equation model (SEM) (Figure 1) in which each measure was treated as a latent variable, consisting of all of its original items as indicators.

\section{RESUlts}

CFC was found to be positively correlated with F-ZTPI; $r=.34(\mathrm{p}<.001)$. Table 1 presents the regression coefficients of F-ZTPI $\left(\beta_{1}\right)$ and CFC $\left(\beta_{2}\right)$ on each of the environmental variables. All models fitted the data reasonably well.

Table 1 - Standardized regression coefficient of CFC and F-ZTPI on environmental variables $(n=361)$

\begin{tabular}{|l|c|c|c|c|c|c|}
\hline \multirow{2}{*}{ Environmental variables. } & \multicolumn{2}{|c|}{ Measures of FO } & \multicolumn{4}{c|}{ Model fit statistics } \\
\cline { 2 - 7 } & $\begin{array}{c}\text { F-ZTPI } \\
\left(\beta_{1}\right)\end{array}$ & $\begin{array}{c}\text { CFC } \\
\left(\beta_{2}\right)\end{array}$ & $\chi^{2} / \mathrm{df}$ & CFI & NFI & RMSEA \\
\hline Attitudes & $.02 \mathrm{~ns}$ & $.25^{* * *}$ & 1.658 & .911 & .806 & .043 \\
\hline Perceived severity & $-.13^{*}$ & $.29^{* * *}$ & 1.717 & .924 & .838 & .045 \\
\hline Efficacy & $.01 \mathrm{~ns}$ & $.30^{* * *}$ & 1.579 & .922 & .817 & .040 \\
\hline WTS & $-.18^{*}$ & $.39^{* * *}$ & 1.708 & .904 & .800 & .044 \\
\hline Behavior (with personal benefit) & $.16^{*}$ & $.15^{*}$ & 1.746 & .913 & .822 & .046 \\
\hline Behavior (without benefit) & $-.12 \mathrm{~ns}$ & $.36^{* *}$ & 1.694 & .902 & .795 & .044 \\
\hline
\end{tabular}

${ }^{*} \mathrm{p}<.05,{ }^{* *} \mathrm{p}<.01,{ }^{* * *} \mathrm{p}<.001$

F-ZTPI scores significantly and negatively predicted perceived severity of environmental problems, WTS and, negatively yet not significantly, behavior without personal benefit. Higher F-ZTPI scores did not result in significantly higher scores in environmental attitudes and environmental efficacy. The only variable that showed significant higher levels with higher F-ZTP was behavior with personal benefit. On the contrary, CFC scores significantly and positively predicted all of the environmental variables. The highest positive effect was on WTS and on behaviors without personal benefits.

\section{Discussion AND CONCLUSIONS}

The present study suggests that "future orientation" is not a simple univalent entity, but may represent different and not necessarily coherent contents such as mental, planning and self-regulation skills as well as tendencies and motivations to consider future implications of present actions. It appears that those scoring high on F-ZTPI did not view the future 
of the environment as a value which is worth a present sacrifice, or they did not view an environmental development as a scenario which is likely to affect their own personal future. F-ZTPI describes skills of time management, delay of gratification, and sticking to a time schedule. In certain contexts (personal-private), these skills may be critical for ensuring future developments which may benefit the individual but not necessarily the environment. In comparison, all CFC items deal with quantifying the relative weight granted by the individual in the present to future implications in general, and are not phrased specifically to the future of the individual him/herself. These findings raise the question of which "future" is measured by the two constructs. In this study, the only variable predicted by the two constructs in a similar pattern was the behavior with personal benefit. Perhaps only when FO is measured in private contexts is there greater consistency in the predictive patterns of the two constructs. Behaviors without personal benefit are better predicted by $\mathrm{CFC}$, indicating that $\mathrm{CFC}$ reflects long-term considerations which refer to the future in general, not only the future of the individual him/herself. Zimbardo \& Boyd (1999, p.1281), describe the "prototype" of the future oriented individuals (according to F-ZTP) as ..."highly organized, ambitious goal seekers who felt pressed for time but were willing to sacrifice present enjoyment to achieve their career objectives". They are characterized as self-centered and reward-dependent, who waste no time on hanging out with friends or even making them in the first place. These qualities do not necessarily contribute to the development of concern and pro-environmental behavior, and perhaps the opposite may be true. Perhaps the ambitions and the self-centeredness characterizing those who scored high on ZTPI, combined with the ability to sacrifice comfort for (private) future interests, are intended primarily to benefit their own private future. The social deficit which they are willing to pay should actually hint at lower social concern. This reinforces previous findings that ZTPI successfully predicted attitudes and behaviors directed to future results in the personal realm (studies, health) but not in the environmental area, which is not solely personal (Carmi, 2012). To sum up, the inconsistency between the predictabilities of the two constructs seems to be context-dependent, and may reveal and expose conflicting interests between the "futures" people are orienting to. The correlation found between the two constructs $(r=0.34)$ has been documented previously in the range of $0.3-0.5$. This means that even though the two constructs provide $10 \%$ of the shared variance, it is quite possible that the remaining $90 \%$ of variance, stemming from other sources representing other dimensions, will refer to other qualities in a different and even opposite way. Finally, this research has demonstrated that FO is a significant predictor of attitudes and behavior in temporal conflict situations. The studied instruments may offer equivalent predictions in areas in which personal and non-personal futures are not at odds. But when temporal conflicts involve social conflicts, as in the environmental context, the two measures of FO may have different and even opposing effects on attitudes and behaviors. Further research, using both instruments along with various psychological variables and in additional contexts, is warranted to understand the differences and to better adapt the instrument to the studied realm. 


\section{REFERENCES}

Adams, J., \& Nettle, D. (2009). Time perspective, personality and smoking, body mass, and physical activity: An empirical study. British Journal of Health Psychology, 14, 83-105.

Carmi, N. (2012). Caring about Tomorrow: Future Orientation, Environmental Attitudes and Behaviors. Accepted for publication.

Crockett, R. A., Weinman, J., Hankins, M., \& Marteau, T. (2009). Time orientation and healthrelated behaviour: Measurement in general population samples. Psychology and Health, 24, 333-50 .

Goldman, D., Yavetz, B., \& Peer, S. (2006). Environmental literacy in teacher training in Israel: Environmental behaviour of new students. The Journal of Environmental Education, 38, 3-22.

Joireman, J. A. (2005). Environmental problems as social dilemmas: The temporal dimension. In A. Strathman, \& J. Joireman (Eds.), Understanding behaviour in the context of time (pp. 289-304). Lawrence Erlbaum Associates, Publishers.

Peer, S., Goldman, D. \& Yavetz, B. (2007). Environmental literacy in teacher training: Attitudes, knowledge, and environmental behavior of beginning students. The Journal of Environmental Education, 39, 45-59.

Strathman, A., Gleicher, F., Boninger, D. S., \& Edwards, C. S. (1994). The consideration of future consequences: Weighing immediate and distant outcomes of behaviour. Journal of Personality and Social Psychology, 66, 742-752.

Zimbardo, P. G., \& Boyd, J. N. (1999). Putting time in perspective: A valid, reliable individualdifferences metric. Journal of Personality and Social Psychology, 77, 1271-1288.

Zimbardo, P. G., \& Boyd, J. N. (2008). The time paradox. New York: Free Press. 